\title{
Protecting The Rights OF ChILdREn OF SAME-SEX PARENTS IN INDIANA BY AdOPTING A VERSION OF THE UNIFORM PARENTAGE ACT
}

\author{
ELIZABETH TRAYLOR*
}

\section{INTRODUCTION}

On October 31, 2013, the Indiana Court of Appeals issued an opinion in the matter of A.C. v. N.J., a custody dispute that involved a same-sex couple and the child that they conceived together through artificial reproductive technology ("ART"). ${ }^{1}$ In that opinion, the court called on the Indiana legislature to fill the gap in Indiana law for non-traditional families such as this one. ${ }^{2}$ This occasion was not the first time, nor will it likely be the last, that a court has asked the legislature to devise a legal framework for the growing number of non-traditional families in Indiana; however, the legislature has yet to act. ${ }^{3}$ Despite the rapidly growing number of families created by same-sex and heterosexual couples through ART, Indiana law has yet to grow with them. ${ }^{4}$ Indiana law currently defines "parent" narrowly, ${ }^{5}$ which ultimately results in some children being deprived of fundamental parental relationships; families that are unrecognized by Indiana law; and judges sorting out this legal uncertainty in court rooms.

Part I of this Note gives a brief overview of the history of parentage laws in the United States and discusses how the U.S. Supreme Court established a standard for determining paternity that defined a father's constitutional right to be a parent. Next, Part II discusses the current state of Indiana statutes and case law as they pertain to families and parentage, and demonstrates how these tools are failing Indiana families. This lack of guidance creates practical problems in Indiana courts, generates uncertainty among families, and often deprives children of important relationships in their lives. Part III discusses the nature of the problem as the numbers of non-traditional families in Indiana and the United States grow, and shows that the children of these families have similar due process and equal protection rights to a family that the U.S. Supreme Court has recognized for adults. Finally, Part IV explores ways to fill Indiana's legal gap, ultimately proposing that Indiana adopt its own version of the Uniform Parentage

* J.D. candidate, 2015, Indiana University Robert H. McKinney School of Law; B.A., 2002, John Carroll University, Cleveland, Ohio.

1. A.C. v. N.J., 1 N.E.3d 685, 687 (Ind. Ct. App. 2013).

2. Id. at 692 .

3. See In re A.B., 818 N.E.2d 126, 131 (Ind. Ct. App. 2004), vacated by King v. S.B., 837 N.E.2d 965 (Ind. 2005) ("We encourage the Indiana legislature to help us address this current social reality by enacting laws to protect children who, through no choice of their own, find themselves born into unconventional familial settings.").

4. The Williams Institute, Indiana Census Snapshot: 2010 (2010), available at http://williamsinstitute.law.ucla.edu/wp-content/uploads/Census2010Snapshot_Indiana_v2.pdf [hereinafter INDIANA CENSUS SNAPSHOT: 2010].

5. IND. CODE $\S 31-9-2-88$ (2013).

http://dx.doi.org/10.18060/4806.0009 
Act ("UPA") as the Indiana Uniform Parentage Act ("INUPA") in order to better address the issues presented by families that Indiana law currently leaves behind.

\section{DEFINING FAMILY AND PARENTAGE}

In the matter of A.C. v. N.J., the Indiana Court of Appeals grappled with the rights of a non-biological parent's visitation rights. The parent was part of a same-sex couple and the child was conceived through ART. ${ }^{6}$ In that case, the court expressed concern over the current state of Indiana law in this area. ${ }^{7}$ In the opinion, Judge Friedlander laments that:

We feel the vacuum of such guidance even more acutely now ... what began as a trickle is rapidly becoming a torrent, and the number of children whose lives are impacted by rules that have yet to be written only increases with the passage of time. They, and we, would welcome a legislative roadmap to help navigate the novel legal landscape in which we have arrived. ${ }^{8}$

Justice Rush, of the Indiana Supreme Court, agreed with Judge Friedlander's concerns and also pointed out this lack of legislative guidance. ${ }^{9}$

The day after A.C. v. N.J. was decided, another case, In re Paternity of Infant $T$, was denied transfer by the Indiana Supreme Court. Justice Rush dissented in that opinion saying that she would "grant transfer ... and leave it to the General Assembly to consider broader legislation to guide and protect future children and families through the still-uncharted waters of assisted reproductive technologies. ${ }^{10}$ In re Paternity of Infant $T$ involved ART and surrogacy. ${ }^{11}$ The biological father sought to disestablish the parentage of the surrogate and establish his paternity as the biological father. ${ }^{12}$ This case is illustrative of the fact that parentage issues also include heterosexual couples who seek to produce children through ART. ${ }^{13}$

Before a discussion can be had about the gaps and deficiencies that exist in Indiana's legal system for certain families, it is necessary to first consider the historical developments that have played a role in defining a family and the

6. A.C., 1 N.E.3d at 685 .

7. Id. at 692 .

8. Id.

9. See, e.g., In re Paternity of Infant T., 999 N.E.2d 843, 843 (Ind. 2013) (Rush, J., dissenting); see also Gary J. Gates, LGBT Parenting in the United States, THE WiLliams InstiTUTE (Feb. 2013), available at http://williamsinstitute.law.ucla.edu/wp-content/uploads/LGBTParenting.pdf, archived at http://perma.cc/T5CN-4VYG.

10. In re Paternity of Infant T., 991 N.E.2d 596 (Ind. Ct. App.), trans. denied, 999 N.E.2d 843 (Ind. 2013) (Rush, J., dissenting).

11. Id.

12. Id.

13. Id. 
current state of the parentage laws in the United States.

\section{A. The Marital Presumption}

Traditionally, the law defined families within the context of marriage under "the marital presumption."14 This doctrine assumed that a mother's husband was a child's father. ${ }^{15}$ This definition of family fulfills several purposes including: efficient identification of a child's father; ${ }^{16}$ legal recognition of a traditional family consisting of a husband, wife, and children; and protecting a child from illegitimacy. ${ }^{17}$ Furthermore, this framework largely identified a father's role as an economic one. Fathers were expected to provide for their children, and their children, in turn, were expected to provide labor. ${ }^{18}$ This economic view of the father's role contributed to the idea that children are their parents' property; this view has been perpetuated in American custody decisions. ${ }^{19}$ One commenter observed that this "enduring legacy of genetic ownership grounded in patriarchal traditions has shaped our legal definition of parenthood." 20 The concept of children as property has resulted in parents' assertions of "rights," and in courts' recognition of a parent's constitutional rights, regarding possession and control of a child. ${ }^{21}$

Although the marital presumption was a useful tool for identifying fathers in eighteenth and nineteenth century England and America, the current definition of parents and families has changed dramatically. ${ }^{22}$ Families are no longer necessarily comprised of a mother, father, and children. It is increasingly unlikely today that children are cared for solely by a stay-at-home parent. ${ }^{23}$ Rather, in 1999, over two thirds of preschool children were cared for by people other than their parents. ${ }^{24}$

Additionally, according to the Centers for Disease Control, almost forty-one percent of births in 2011 were to unmarried women. ${ }^{25}$ The changes in the

14. Jane C. Murphy, Legal Images of Fatherhood: Welfare Reform, Child Support Enforcement, and Fatherless Children, 81 Notre DAME L. REV. 325, 326 (2005).

15. Id.

16. Melanie B. Jacobs, Overcoming the Marital Presumption, 50 FAM. CT. REV. 289, 290 (2012).

17. Murphy, supra note 14 , at 326.

18. Id.

19. Id.

20. Barbara Bennett Woodhouse, Hatching the Egg: A Child-Centered Perspective on Parents' Rights, 14 CARDOZO L. REV. 1747, 1811 (1993).

21. See id.

22. Murphy, supra note 14, at 326.

23. Matthew M. Kavanagh, Rewriting the Legal Family: Beyond Exclusivity to a Care-Based Standard, 16 YALE J.L. \& FEMINISM 83, 93 (2004).

24. Id.

25. Joyce A. Martin, M.P.H. et al, National Vital Statistics Report, Vol. 62 No. 1 (June 28, 2013), available at http://www.cdc.gov/nchs/fastats/unmarried-childbearing.htm, 
structure, the increase in the birthrate outside of marriage, the legal legitimacy of non-marital children, and scientific advances that allowed for easier determination of paternity all led to a shift in the definition of parent recognized by the U.S. Supreme Court. ${ }^{26}$ Once the marital presumption was no longer a reliable indicator of fatherhood, the role of a father began to expand beyond the financial aspects. ${ }^{27}$ Unmarried fathers were permitted to prove their status as a "legal father" by showing both their "biological connection" and that they had forged a relationship with the child. ${ }^{28}$ Several U.S. Supreme Court decisions in the 1970s confirmed a parent's constitutional right to be a parent on equal protection $^{29}$ and due process grounds through what has been referred to as the "biology plus" test. ${ }^{30}$

\section{B. The U.S. Supreme Court and "Biology Plus"}

The U.S. Supreme Court rarely decides domestic relations issues because family law is within the purview of the states. ${ }^{31}$ However, in the few cases the Court has taken up regarding domestic relations issues, the Court has confirmed a parent's liberty interest in the "companionship, care, custody, and management of his or her children." ${ }^{32}$ The U.S. Supreme Court has also had several occasions to decide issues of paternity.

In one of the first paternity cases, Stanley v. Illinois, the Court recognized the liberty interest of an unmarried biological parent. ${ }^{33}$ There, an unmarried father and mother with three children lived together for eighteen years. ${ }^{34}$ After the mother died, the children were taken away from their father, and became wards of the state because Illinois law did not recognize unwed fathers as legal parents. ${ }^{35}$ The Court found that the father had valid claims on both equal

archived at http://perma.cc/N9UN-GN5N.

26. Murphy, supra note 14, at 326; see, e.g., Stanley v. Illinois, 405 U.S. 645 (1972).

27. Murphy, supra note 14, at 344.

28. Id. at 337.

29. The Due Process Clause of the Fourteenth Amendment to the U.S. Constitution provides that no state shall "deprive any person of life, liberty, or property, without due process of law." U.S. CONST. amend. XIV, § 1. See also Meyer v. Nebraska, 262 U.S. 390, 390 (1923) ("[W]ithout due process of law, 'liberty' denotes, not merely freedom from bodily restraint, but also the right of the individual to ... marry, establish a home, and bring up children, ... and generally to enjoy those privileges long recognized at common law as essential to the orderly pursuit of happiness by free men.").

30. Melanie B. Jacobs, My Two Dads: Disaggregating Biological and Social Paternity, 38 ARIZ. ST. L.J. 809, 827 (2006).

31. See In re Burrus, 136 U.S. 586, 586 (1890).

32. Stanley v. Illinois, 405 U.S. 645, 651 (1972); see also Pierce v. Soc'y of the Sisters of the Holy Names of Jesus \& Mary, 268 U.S. 510 (1925); Meyer v. Nebraska, 262 U.S. 390 (1923).

33. Stanley, 405 U.S. at 646.

34. Id.

35. Id. at 647 . 
protection and due process grounds because the vital interest a man has, "in the children he has sired and raised, undeniably warrants deference and, absent a powerful countervailing interest, protection." 36 After Stanley was decided, the Court issued three opinions dealing with step-parent adoption and paternity, which established the "biology plus" standard..$^{37}$ This standard required men to demonstrate, in addition to their biological connection to a child, that they "had actively engaged in parenting." 38

In the most recent related U.S. Supreme Court decision, Lehr v. Robinson, Justice Stevens noted that biology is merely a starting point for a parental right, noting that:

[T] he significance of the biological connection is that it offers the natural father an opportunity that no other male possesses to develop a relationship with his offspring. If he grasps that opportunity and accepts some measure of responsibility for the child's future, he may enjoy the blessings of the parent-child relationship and make uniquely valuable contributions to the child's development. If he fails to do so, the Federal Constitution will not automatically compel a State to listen to his opinion of where the child's best interests lie. ${ }^{39}$

This line of cases following Stanley indicate that the U.S. Supreme Court favors a "family unit," yet caution that a father risks losing his parental rights if he does not actively parent a child. ${ }^{40}$ The U.S. Supreme Court appears to prefer a "family unit" that is comprised of parents who are actively parenting, regardless of their biological connection to the child. ${ }^{41}$ If, according to the Court, biology is not enough for establishing a parental relationship, then in the context of samesex parentage, perhaps a parent without a biological connection, such as a nonbiological same-sex mother, could establish parentage through demonstrating a "full commitment to the responsibilities of parenthood." 42 Although the Court has not expressly decided a case involving the scope of same-sex parenting rights, precedent shows the Court's interest in protecting established, functioning family units. Nevertheless, states need not wait for the U.S. Supreme Court to evaluate

36. Id. at 651 .

37. Murphy, supra note 14, at 336. See Lehr v. Robertson, 463 U.S. 248, 262 (1983) (declining to extend constitutional protection to a biological father's rights to his daughter); Caban v. Mohammed, 441 U.S. 380, 394 (1979) (holding that a father's equal protection and due process rights were violated because adoption statute "discriminate[d] against unwed fathers even when their identity [was] known and they [had] manifested a significant paternal interest in the child"); Quilloin v. Walcott, 434 U.S. 246, 255 (1978) (holding that adoption of son by mother's new husband was not a violation of biological father's rights because he never sought physical or legal custody of his son and the Court was protecting "a family unit already in existence").

38. Jacobs, supra note 30 , at 828 .

39. Lehr, 463 U.S. at 262.

40. See id. at 267.

41. See id. at 268 .

42. Id. at 248 . 
the constitutional rights of a same-sex parents, and they are free to enact laws defining parentage within the guidelines the Court has set forth.

\section{Current State of PARENTAge In Indiana}

\section{A. The Indiana Code}

In 1997, the Indiana General Assembly rewrote the family and juvenile laws of Indiana so that they would be "clear, concise, and easy to interpret and apply." 43 While that goal might have been accomplished in 1997, the Indiana Code still has gaps that exclude many Indiana families. The Indiana Code narrowly defines a parent as "a biological or an adoptive parent." 44 It further provides that " $[\mathrm{u}]$ nless otherwise specified, the term includes both parents, regardless of their marital status." $" 45$ This also includes an "alleged father,"46 which is "any man claiming to be or charged with being a child's biological father." 47 There is not an Indiana statute that provides for the intent of parents to raise a child as their own, recognized as "intentional parents," 48 except in surrogacy situations $;{ }^{49}$ however, Indiana does recognize a de facto custodian as:

[A] person who has been the primary caregiver for, and financial support of, a child who has resided with the person for at least:

(1) six (6) months if the child is less than three (3) years of age; or

(2) one (1) year if the child is at least three (3) years of age..$^{50}$

Although the intent of this statute is to allow third parties to have standing in determining the custody of a child, ${ }^{51}$ there is still a presumption in favor of the biological parent that must be overcome in order to show that a de facto custodian is in the best interests of the child. ${ }^{52}$ Indiana law does provide for a presumption of paternity in cases where the "man and the child's biological mother are or have been married to each other" and if the child is born "not later than three hundred

43. IND. CODE $\S 31-10-1-1$ (2013).

44. Id. §31-9-2-88(a).

45. Id.

46. Id. § 31-9-2-9.

47. Id. $\S 31-9-2-88(\mathrm{~b})$.

48. California law provides that a "presumed parent" could be one who "receives the child into his or her home and openly holds out the child as his or her natural child." CAL. FAM. CODE $\S 7611(\mathrm{~d})$ (West 2013).

49. See IND. CODE $§ 31-9-2-63$ (2013) (providing that an "intended biological parent" is one who is a "party to a surrogate agreement who: (1) agrees to be or is genetically related to a child borne by a surrogate; and (2) is not the surrogate's spouse.").

50. Id. § 31-9-2-35.5.

51. See In re Guardianship of L.R.T. \& A.J.B., 979 N.E.2d. 688 (Ind. Ct. App. 2012), trans. denied, 938 N.E.2d 1157 (Ind. 2013); A.J.L. v. D.A.L., 912 N.E.2d 866 (Ind. Ct. App. 2009).

52. In re Guardianship of L.R.T. \& A.J.B., 979 N.E.2d. at 690. 
(300) days after the marriage is terminated by death, annulment, or dissolution. ${ }^{, 53}$ Indiana law also recognizes paternity in cases where a marriage is void due to a prior existing marriage, ${ }^{54}$ between cousins,${ }^{55}$ and involves mental incompetence. ${ }^{56}$ This is in line with Indiana's general policy that informs the family law that seeks to "recognize the importance of families and children in our society," provisions seek to protect children by establishing paternity even when there is a marriage that Indiana law does not recognize. ${ }^{58}$ The gaps in the Indiana Code have resulted in case law that does not provide much guidance to families, judges, and lawyers as they seek to protect different types of families in Indiana, especially same-sex families.

\section{B. Indiana Case Law}

As A.C. v. N.J. illustrates, Indiana case law does not provide much guidance for same-sex couples. ${ }^{59}$ In this case, two women who had been together for two years and had celebrated a commitment ceremony decided to conceive a child through artificial insemination. ${ }^{60}$ The biological mother carried the child while her partner worked and supported the family financially. ${ }^{61}$ Their son was born in April, 2008. ${ }^{62}$ The partner was present at the birth of the child and cut the umbilical cord. ${ }^{63}$ The family lived together for two years as a "family unit." There was discussion of the partner adopting the child, but no one ever started the process. ${ }^{65}$ This was mainly due to the expense of an adoption, and the partner and mother had already agreed to raise the child together. ${ }^{66}$ In 2010 , the biological mother and the partner ended their relationship and the partner was allowed visitation time with the child, while the biological mother had primary custody. ${ }^{67}$ Eventually, this arrangement ceased to work and allegations were made of the partner not providing any financial support. ${ }^{68}$ When the biological mother denied

53. IND. CODE $\S 31-14-7-1$ (2013).

54. Id. $\S 31-11-8-2$.

55. Id. $\S 31-11-8-3$.

56. Id. $\S 31-11-8-4$.

57. Id. $\S 31-10-2-1$.

58. Id. $\S 31-11-1$.

59. A.C. v. N.J., 1 N.E.3d 685, 687 (Ind. Ct. App. 2013).

60. Id.

61. Id.

62. Id.

63. Id.

64. Id.

65. Id.

66. Brief for Appellant at 4, A.C. v. N.J., 1 N.E.3d 685 (Ind. Ct. App. 2013) (No. 20A041301-DR-37).

67. A.C., 1 N.E. $3 \mathrm{~d}$ at $687-88$.

68. Id. at 688 . 
the partner access to the child, the partner filed a suit seeking custody. ${ }^{69}$

In the suit, the partner asserted three theories as to why she should be granted custody of the child even though she was not biologically related to the child and was, under Indiana law, a legal stranger to the child. ${ }^{70}$ The first theory was that it was the intention of the parties that they would both be considered the child's parents, the second was that it was in the child's best interest that she have custody, and finally, that she was a "de facto custodian." 71 The trial court rejected all three of these arguments and concluded that the partner did not even have standing to bring a suit for visitation. ${ }^{72}$ It is necessary here to engage in a brief discussion of which parties in Indiana can and cannot bring custody and visitation suits.

Standing in a custody dispute refers to which parties can bring a suit for custody or visitation. ${ }^{73}$ Typically, this regards the parents of a child, ${ }^{74}$ but Indiana case law varies as to which parties might have that ability to bring these types of challenges. The existing case law recognizes that step-parents might have standing in a custody proceeding. ${ }^{75}$ Furthermore, the Indiana legislature created the Grandparent Visitation Act ${ }^{76}$ which "left the development of the law on the rights of parties, other than parents and grandparents, to the sound discretion of the courts." 77

Indiana jurisprudence responded to the U.S. Supreme Court's decision in Troxel v. Granville, which drastically limited third-party rights of visitation by giving great weight to a parent's decision. ${ }^{78}$ The Indiana courts concluded that when considering visitation, they would consider the following factors: "the presumption that a fit parent acts in his or her child's best interests, the special weight afforded a fit parent's decision to deny visitation, and whether the parent

69. Id.

70. Id. at 687 .

71. Id. at 688 .

72. Id. at 694 .

73. Black's LAW DiCTIONARY Standing (9th ed. 2009).

74. Id.

75. See Collins v. Gilbreath, 403 N.E.2d 921, 923-24 (Ind. Ct. App. 1980) (holding that awarding visitation to a step-father was proper in light of the fact that the children had recently lost their mother and this would help the transition to their new life with their biological father, but also noting that the holding was narrow and was not extended to unrelated third persons or grandparents).

76. IND. CODE § 31-1-11.7-2 (repealed 1997).

77. Tinsley v. Plummer, 519 N.E.2d 752, 754 (Ind. Ct. App. 1988).

78. In Troxel v. Granville, a mother wanted to limit the time her children spent with their paternal grandparents following the death of her husband, but a Washington statute allowed for any person to petition for custody at any time and the paternal grandparents sought visitation. The U.S. Supreme Court concluded that the statute was too broad and infringed on a biological mother's substantive due process rights to make decisions in the best interests of her children. Troxel v. Granville, 530 U.S. 57 (2000). 
had denied or simply limited visitation." ${ }^{\prime 79}$ Although Indiana courts were showing great deference to parental decisions regarding visitation, the courts did not specifically limit third-party standing only to step-parents. ${ }^{80}$ However, in Worrell v. Elkhart County Office of Family \& Children, the Indiana Supreme Court concluded that foster parents did not have standing as third-parties seeking visitation, thus setting an actual limitation on who could seek visitation. ${ }^{81}$

Although these decisions affect step-parents, grandparents, and foster parents, the rights of same-sex parents remain largely undefined. ${ }^{82}$ In terms of same-sex standing, there is uncertainty regarding "whether former same-sex partners might fall within the class of nonparents with standing to seek third-party visitation." 83 Although in A.C. v. N.J. the trial court concluded that the partner did not have standing to seek custody, the Indiana Court of Appeals concluded that the partner did have standing to seek custody of the child. The Indiana Court of Appeals noted that it was likely that "custodial and parental relationships may exist with third parties other than stepparents." ${ }^{84}$ In coming to this conclusion, the Indiana Court of Appeals looked at the facts that indicated what kind of relationship the partner had with the child, including the partner's and the biological mother's intent to raise the child together and the parental bond between the partner and the child. ${ }^{85}$ These facts indicated to the court that it was in the best interest of the child to maintain a relationship with the partner. ${ }^{86}$ In the wake of A.C. v. N.J., same-sex couples now have access to the courts when resolving custody disputes, yet it remains largely uncertain what rights the courts will recognize.

Prior to the decision in A.C. v. N.J., Indiana courts had few occasions to decide the rights of same-sex couples in custody cases, ${ }^{87}$ and the jurisprudence that exists is inconclusive. ${ }^{88}$ In addressing the partner's other two arguments, based on the intent of the couple to raise the child together and her status as a de facto parent, the A.C. v. N.J. court looked to a ten-year-old case where it decided a similar same-sex custody issue. That case, In re A.B., involved a same-sex couple that had been in a relationship for nine years and chose to have a child through ART. ${ }^{89}$ When the couple's relationship ended, the biological mother, who carried the child, allowed liberal visitation to her partner who also paid child

79. A.C. v. N.J., 1 N.E.3d 685, 695 (Ind. Ct. App. 2013).

80. Id.

81. Worrell v. Elkhart Cnty. Office of Family \& Children, 704 N.E.2d 1027, 1029 (Ind. 1998).

82. A.C., 1 N.E.3d at 696.

83. Id.

84. Id. at 697.

85. Id. at 693 .

86. Id.

87. See M.S. v. C.S. 938 N.E.2d 278 (Ind. Ct. App. 2010); In re A.B., 818 N.E.2d 126, 131

(Ind. Ct. App. 2004), vacated by King v. S.B., 837 N.E.2d 965 (Ind. 2005).

88. See generally A.C., 1 N.E.3d at 685; In re A.B., 818 N.E.2d at 126.

89. In re A.B., 818 N.E.2d at 128 . 
support. ${ }^{90}$ The biological mother eventually denied visitation to the partner, and the partner filed an action seeking to be recognized as the child's legal parent or, in the alternative, to be recognized as a de facto parent with visitation rights. ${ }^{91}$ The trial court dismissed the case and did not recognize any right for the partner to have visitation with the child. ${ }^{92}$ This is another illustration of the problem that many same-sex parents face when seeking to enforce their parental rights. Until there is a legal recognition of the same-sex parent's role in a child's life, courts will continue to dismiss claims at the outset, similar to the trial court decision in A.C. v. N.J. ${ }^{93}$

In In re A.B., the Indiana Court of Appeals noted that it was "sympathetic" to the claim, and observed a strong "apparent bonding" between the partner and the child. ${ }^{94}$ However, that court also stated that, "it is sufficient to note that [the partner] has no relationship to [the child] within the context of any relationship presently given legal recognition by the State of Indiana that might permit her to claim parentage of [the child]." 95 Just like the court in A.C. v. N.J., this court asked for guidance from the legislature stating, "[it is] sufficiently prescient to anticipate that the law will have to extend some form of recognition to gay and lesbian relationships to create a structure within which a myriad of legal issues emanating from such partnerships." ${ }^{\circ 6}$ What is striking about this statement is that it was made in 2004, more than a decade ago, and the Indiana legislature has yet to act, despite repeated requests for guidance from Indiana courts. ${ }^{97}$

The Indiana Court of Appeals, in In re A.B., ultimately overturned the trial court's dismissal and concluded that, "when two women involved in a domestic relationship agree to bear and raise a child together by artificial insemination of one of the partners with donor semen, both women are the legal parents of the resulting child." Although the opinion from the Indiana Court of Appeals offered much needed guidance, on transfer, the Indiana Supreme Court vacated this opinion. ${ }^{99}$ While the Indiana Supreme Court agreed that the case should not be dismissed for failure to state a claim, it narrowed the holding to a procedural posture. ${ }^{100}$ The Indiana Supreme Court found that "at least some of the relief sought" by the partner fell within the discretion of the trial court to determine because Indiana courts do have the ability to "place a child with a person other

90. Id.

91. Id.

92. See generally id.

93. A.C., 1 N.E.3d at 697.

94. In re A.B., 818 N.E. $2 \mathrm{~d}$ at 128.

95. Id. at 129.

96. Id. at 128-29.

97. See, e.g., id.; see also In re Paternity of Infant T., 991 N.E.2d 596 (Ind. Ct. App.), trans. denied, 999 N.E.2d 843 (Ind. 2013) (Rush, J., dissenting); A.C., 1 N.E.3d at 692.

98. In re A.B., 818 N.E.2d at 131-32.

99. King v. S.B., 837 N.E.2d 965 (Ind. 2005).

100. Id. at 967 . 
than the natural parent."101 The Indiana Supreme Court also recognized that "Indiana law "provide[s] a measure of protection for the rights of the natural parent, but more importantly, it embodies innumerable social, psychological, cultural, and biological considerations that significantly benefit the child and serve the child's best interests." 102 While this opinion seems to open the door for same-sex parents to at least be heard on the issue of visitation, it is hardly a clear path. Justice Dickson, in his dissent, makes it clear that this is not an area that will be easily settled. ${ }^{103}$ In his opinion, this result was not representative of the will of the people of Indiana. ${ }^{104}$ As the court notes in A.C. v. N.J., "the status of the law surrounding a lesbian partner's right, if any, to enjoy the rights of a legal parent of a child ... remains uncertain." 105

In its decision in A.C. v. N.J. the court of appeals looked to the Indiana Supreme Court's decision to vacate In re A.B. for guidance in addressing the de facto parent and intention of the parties claim by the partner. ${ }^{106}$ The court further concluded that in light of the Indiana Supreme Court's apparent disapproval of its decision in In re A.B., it agreed with the trial court and would not enforce an agreement based on the intent of the parties to raise the child together. ${ }^{107}$ The court further added in A.C. v. N.J. that it would leave the decision to recognize that type of agreement to the Indiana Supreme Court. ${ }^{108}$ The A.C. v. N.J. court addressed the de facto parent argument in a footnote, and concluded that even if the partner could be considered a de facto parent, she would have to overcome the presumption in favor of the natural parent, and the Court of Appeals agreed with the trial court that she had not successfully overcome this presumption. ${ }^{109}$ Finally, the court recognized that the partner had standing to seek visitation with the child as a third party and remanded the decision to the lower court to consider the request for visitation. ${ }^{110}$

As A.C. v. N.J. and In re A.B. both illustrate, in same-sex custody and visitation disputes the Indiana courts currently have very few tools. ${ }^{111}$ The Indiana Code provides no avenue for a same-sex parent to assert a right to

101. Id.

102. See id. (citing In re Guardianship of B.H., 770 N.E.2d 283, 287 (Ind. 2002)).

103. See King, 837 N.E.2d at 971 (Dickson, J., dissenting).

104. See id. (Justice Dickson stating, "The common law should not, in my opinion, be used to provide non-statutory privileges arising out of same-sex domestic relationships when, as here, not only is Indiana public opinion deeply fractured, but also a significant majority of Indiana citizens favor a public policy that does not promote same-sex families.”).

105. A.C. v. N.J., 1 N.E.3d 685, 692 (Ind. Ct. App. 2013).

106. Id.

107. $I d$. at 693.

108. Id.

109. Id. at 697 n.6.

110. Id. at 697 .

111. A.C., 1 N.E. 3d at 685; see also In re A.B. 818, N.E.2d 126 (Ind. Ct. App. 2004), vacated by King v. S.B., 837 N.E.2d 265 (Ind. 2005). 
visitation $^{112}$ and Indiana case law does not directly address the practical problems that judges face in resolving these family matters. ${ }^{113}$ The occurrence of these types of issues will continue to grow steadily along with the rise in the number of families being created by same-sex partners. ${ }^{114}$

\section{The Growing Problem And AdDressing the Rights of CHILDREN OF SAME-SEX FAMILIES}

\section{A. The Growing Number of Non-Traditional Families in Indiana and the United States}

As Judge Friedlander correctly points out in A.C. v. N.J., the number of family situations like this are "rapidly becoming a torrent." 115 According to the Centers for Disease Control ("CDC"), the rate of ART has doubled over the past decade with one percent of all births in the United States from ART. ${ }^{116}$ According to a study by the Williams Institute, "[m] ore than 111,000 same-sex couples are raising an estimated 170,000 biological, step, or adopted children [in the United States]." "117 Specifically, Indiana has 11,074 same-sex couples, and nineteen percent of those couples raising their own children. ${ }^{118}$ Families look different than they did decades ago and are being created in a variety of ways, through ART, adoption, divorce, and remarriage. Indiana law has not yet caught up with these changes in families and there continues to be a dearth of legislation to help these families define themselves and gain legal protection.

This problem is only going to become more pronounced after the recent U.S. Supreme Court decision in United States $v$. Windsor. ${ }^{119}$ This decision struck down Section Three of the Defense of Marriage Act ("DOMA"), which defined

112. IND. CODE $\S 31-17-5-1$ (2013).

113. See A.C., 1 N.E.3d at 685.

114. Gates, supra note 9. A poll conducted by Bellweather Research and Consulting on behalf of Freedom Indiana, the organization fighting the legislation that would amend the Indiana Constitution to include a definition of marriage as between one man and one woman, stated that twenty-eight percent of Hoosiers indicate that their support for same-sex marriage has grown over the last few years. See also Memorandum from Bellweather Research and Consulting to Freedom Indiana (Sep. 22, 2013), available at https://docs.google.com/file/d/0B26Q1HJ1fUtGTjV4S 2ZLUkYwM3c/edit, archived at http://perma.cc/DH96-V826.

115. A.C., 1 N.E.3d at 692.

116. Assisted Reproductive Technology: Most Recent ART Data, CENTERS FOR DISEASE CONTROL AND PREVENTION (July 30, 2014, 11:04pm), http://www.cdc.gov/ART, archived at http://perma.cc/UXJ9-SD7B.

117. See Gates, supra note 9.

118. See Indiana CEnSUS SNAPSHOt: 2010, supra note 4.

119. In United States $v$. Windsor, the United Supreme Court held that section 3 of the Defense of Marriage Act ("DOMA"), which defined marriage as between a man and a woman, violated the Fifth Amendment and was therefore unconstitutional. United States v. Windsor, 133 S. Ct. 2675 (2013). 
marriage as between a man and a woman, as a violation of the Fifth Amendment. ${ }^{120}$ Justice Kennedy noted in the opinion, that the DOMA "makes it even more difficult for the children to understand the integrity and closeness of their own family and its concord with other families in their community and in their daily lives." 121 This is also true for families affected by the void of state legislation recognizing families that might not be created in the traditional mold of two married, opposite sex parents and their biological children. Indiana also has a statute that recognizes marriage as only between a man and a woman. ${ }^{122}$ Additionally, the statute provides, "[o]nly a female may marry a male" and that "[o]nly a male may marry a female." ${ }^{123}$ Furthermore, the Indiana Code states that Indiana will not recognize "[a] marriage between persons of the same gender . . . even if the marriage is lawful in the place where it is solemnized." ${ }^{24}$ Not only does Indiana not recognize same-sex marriage at all, even couples who have a legal same-sex marriage in another state have no legal status in Indiana. ${ }^{125}$ This presents numerous problems for same-sex families that choose to move to Indiana. For example, if a same-sex couple that is legally married in a state that recognizes same-sex marriage, such as Iowa, ${ }^{126}$ moves to Indiana, the state would not recognize their marriage. ${ }^{127}$ Additionally, any children they might have would need to be adopted. ${ }^{128}$ Furthermore, the couple would no longer have the right to visit each other in the hospital, make medical decisions, gain access to the family court system, or to any child support statutes. ${ }^{129}$ It is difficult to meet the best interests of a child when the state of Indiana does not recognize or protect that child's family structure. ${ }^{130}$

Without a clear directive from the legislature, the Indiana courts are forced

120. DOMA was passed by Congress in 1996 and was signed into law by President Clinton. Section 2 provides that States do not have to recognize "a relationship between persons of the same sex that is treated as a marriage under the laws of such other State, territory, possession, or tribe, or a right or claim arising from such relationship," while section 3 defines marriage as between one man and one woman. 28 U.S.C.A. § 1738C; 1 U.S.C.A. § 7.

121. Windsor, $133 \mathrm{~S}$. Ct. at 2694.

122. IND. CODE $\S 31-11-1-1$ (2013).

123. Id.

124. Id.

125. See id.

126. See Jeff Eckhoff \& Grant Schulte, Unanimous Ruling: Iowa Marriage No Longer Limited to One Man, One Woman, DeS MoINES REGISTER (Apr. 3, 2009), http://www. desmoinesregister.com/article/20090403/NEWS/90403010, archived at http://perma.cc/KL4S5UKU (In 2009, Iowa became the third state to legalize same-sex marriages).

127. See In re Adoption of K.S.P., 804 N.E.2d 1253 (Ind. Ct. App. 2004) (holding that a samesex partner may adopt biological children of her partner).

128. Id.

129. Evan Wolfson, Protections Denied to Same Sex Couples and Their Kids, from Why Marriage Matters: Appendix B, FREEDOM TOMARRY http://www.freedomtomarry.org/pages/fromwhy-marriage-matters-appendix-b-by-evan-wolfson, archived at http://perma.cc/5GGS-KJES.

130. IND. CODE $\S 31-11-1-1$ (2013). 
to make important decisions about parentage based on precedent that is murky at best. ${ }^{131}$ The legislature needs to act to protect these families and children. The definition of "parent" has changed dramatically over the past several decades and the law needs to be flexible in order to accommodate these new family structures.

\section{B. The Substantive Due Process and Equal Protection Rights of Children}

Courts routinely make decisions regarding the rights of parents in custody cases. As discussed previously, the concept of "biology plus," used by the U.S. Supreme Court in unwed father cases, confirmed a parent's constitutional right to be a parent on equal protection and due process grounds. ${ }^{132}$ Additionally, A.C. $v$. N.J. indicates that, in Indiana, same-sex parents likely have standing to seek custody while their actual rights remain undetermined. ${ }^{133}$ What is less defined, and equally important, is whether children have a substantive due process or equal protection right to maintain a relationship with a parent. Children do have constitutional rights, and the U.S. Supreme Court has recognized children's rights in several instances. ${ }^{134}$ In Wisconsin v. Yoder, the Court noted that "children are 'persons' within the meaning of the Bill of Rights. We have so held over and over again." 135 Additionally, the U.S. Supreme Court has held that "neither the Fourteenth Amendment nor the Bill of Rights is for adults alone."136 While courts, including the U.S. Supreme Court, have not explicitly determined the substantive due process rights of children, these same courts have not explicitly denied the existence of the right either.

1. The U.S. Supreme Court and the Substantive Due Process Rights of Children.- In 1989, just after the Court decided the line of cases that established the "biology plus" standard for unwed fathers, it decided the case of Michael H. $v$. Gerald $D .{ }^{137}$ In this case, a married woman began having an affair with her neighbor, became pregnant, and had a daughter. ${ }^{138}$ Eventually, the relationship soured and the mother returned, with the child, to her husband. The neighbor filed an action to establish his paternity rights and allow for visitation. ${ }^{139}$ Eventually, the husband intervened, citing California law, which presumes that a husband cohabiting with his wife is the father of any children born of the marriage. ${ }^{140}$ The neighbor challenged the California law as a violation of his procedural and substantive due process rights. ${ }^{141}$ The parents, on behalf of the

131. See generally A.C. v. N.J., 1 N.E. 3d 685, 692 (Ind. Ct. App. 2013).

132. Jacobs, supra note 30 , at 827.

133. A.C. v. N.J., 1 N.E. 3d 685, 692 (Ind. Ct. App. 2013).

134. See, e.g., Wisconsin v. Yoder, 406 U.S. 205 (1972) (Douglas, J., dissenting).

135. Id. at 243.

136. In re Gault, 387 U.S. 1, 13 (1967).

137. See generally Michael H. v. Gerald D., 491 U.S. 110 (1989).

138. Id. at 113 .

139. Id. at 114 .

140. Id. at 116 .

141. Id. 
daughter, also raised a due process argument and asserted "that if she had more than one psychological or de facto father, she was entitled to maintain her filial relationship, with all of the attendant rights, duties, and obligations, with both."142

Ultimately, the Court rejected the neighbor's procedural due process argument, and in addressing the substantive due process argument, the Court recognized that there is a fundamental liberty interest in preserving a father's relationship with a child. ${ }^{143}$ The Court took a different angle, when it said, "the natural father's unique opportunity conflicts with the similarly unique opportunity of the husband of the marriage; and it is not unconstitutional for the State to give categorical preference to the latter." 144 In assessing the daughter's substantive due process right to a relationship with her biological father, the Court said that it has "never had occasion to decide whether a child has a liberty interest, symmetrical with that of her parent, in maintaining her filial relationship. We need not do so here because, even assuming that such a right exists, [the daughter's] claim must fail." 145 The Court goes on to say that even if the child "has a liberty interest in maintaining a filial relationship with her natural father, [the neighbor] we find that, at best, her claim is the obverse of [her natural father's] and fails for the same reasons." 146 While the Court in Michael H. denied the daughter's substantive due process claim, it did not do so because the right did not exist. ${ }^{147}$ Rather, the Court denied the claim because recognition of the right would acknowledge a parental relationship with two fathers and that fell outside the norm of what the Court conceived as a traditional family relationship. ${ }^{148}$ Instead, the Court chose not to decide whether she has the right. ${ }^{149}$

In a more recent case, Adoptive Couple v. Baby Girl, the U.S. Supreme Court again declined to discuss a child's substantive due process right to maintain a parental relationship. ${ }^{150}$ In that case, a woman discovered that she was pregnant and after her relationship with the baby's father, a Cherokee Indian, deteriorated she sent him a text message asking if he would give up his parental rights. ${ }^{151} \mathrm{He}$ assented and the mother proceeded with the adoption process and chose an adoptive couple from South Carolina. ${ }^{152}$ After consenting to the adoption, the biological father challenged it in South Carolina; the South Carolina Family Court found the adoption to be invalid. ${ }^{153}$ The South Carolina Supreme Court affirmed, and the twenty-seven-month-old baby girl was returned to her

142. $I d$. at 114 .

143. Id. at 122 .

144. Id. at 129 .

145. Id. at 130 .

146. Id. at 131 .

147. Id. at 128 .

148. Id. at 130 .

149. Id. at 131-32.

150. See generally Adoptive Couple v. Baby Girl, 133 S. Ct. 2552 (2013).

151. Id. at 2558 .

152. Id.

153. Id. at 2559 . 
biological father whom she had never met, after living with the adoptive couple for the first twenty-seven months of her life. ${ }^{154}$ On appeal, the U.S. Supreme Court held that the adoption was valid because a Federal statute protecting Native American children was not applicable to the biological father because he never had "legal or physical custody" of the baby girl as of the time of the adoption proceedings. ${ }^{155}$ That decision legitimized the adoption, and she was eventually returned to the adoptive couple. ${ }^{156}$

In a brief to the U.S. Supreme Court, the baby girl's liberty interest in maintaining a relationship with her biological father was argued on her behalf. ${ }^{157}$ The brief stated that "foremost among these 'intimate human relationships' is 'the creation and sustenance of a family." 158 Additionally, it was argued that children as well as adults have a liberty interest in preserving their familial relationships. ${ }^{159}$ Similar to Michael $H$, the majority did not make a decision regarding the baby girl's liberty interest in maintaining a relationship with her biological father. Although, Justice Sotomayor recognized in her dissent that biological fathers have an interest in forming a relationship with their children and that "children have a reciprocal interest in knowing their biological parents." ${ }^{160}$ This notion of a "reciprocal right" for children, cited by Justice Sotomayor, originated in another U.S. Supreme Court case, Santosky v. Kramer. ${ }^{161}$

Santosky v. Kramer was decided in 1982 and involved a challenge to a New York statute that allowed for the termination of parental rights if the state finds that child is "permanently neglected." 162 In Santosky, the state permanently removed three children from their parents due to "incidents reflecting parental neglect." 163 The parents challenged the removal of their children as a violation of their due process rights. ${ }^{164}$ The Court held that the parents' due process rights were violated and that before a state can remove children from their parents, there needs to be a showing of clear and convincing evidence of neglect. ${ }^{165}$ In coming to this decision, the Court stated that "the child and his parents share a vital interest in preventing erroneous termination of their natural relationship" and that

154. Id.

155. Id. at 2562 .

156. South Carolina Drops Extradition Request for Baby Veronica's Father, ASSOCIATED PRESS(Oct. 2, 2013, 9:26 PM), http://www.cbsnews.com/8301-201_162-57605799/south-carolinadrops-extradition-request-for-baby-veronicas-father/, archived at $\mathrm{http} / /$ perma.cc/7WAN-VMXY.

157. Brief for Guardian Ad Litem, as Representative of Respondent Baby Girl at 56, Adoptive Couple v. Baby Girl, 133 S. Ct. 2553 (2013) (No. 12-399) (quoting Roberts v. U.S. Jaycees, 468 U.S. 609, 617-19 (1984)).

158. Id.

159. See generally id.

160. Adoptive Couple, 133 S. Ct. at 2582.

161. Id.

162. Santosky v. Kramer, 455 U.S. 745, 747 (1982).

163. Id. at 750 .

164. Id.

165. See generally id. at 747-48. 
"the interests of the child and his natural parents coincide."166 The Court also noted that this loss is "far-reaching" and extends to the loss of support, maintenance, and inheritance. ${ }^{167}$ Here, the U.S. Supreme Court acknowledged the reciprocal rights that children have to a relationship with their parents. ${ }^{168}$

Finally, in Roe v. Conn, a case decided by the District Court of Alabama, the court stated that the Constitution recognizes a "fundamental right to family integrity." 169 In this case, a child was removed from his mother's home without notice or a hearing. ${ }^{170}$ The action was premised on an Alabama statute that allowed for the summary removal of a child if a juvenile court judge believed removal was necessary for the child's welfare. ${ }^{171}$ The mother and child challenged the statute and the District Court concluded that because of the existence of a fundamental right to family integrity, the "state's severance of [the mother's] parent-child relationship and of [the child's] child-parent relationship will receive strict judicial scrutiny." 172 In applying the strict scrutiny standard to the Alabama statute, the court in this case held that the statute was unconstitutional. ${ }^{173}$ This case demonstrates a court's willingness to recognize a fundamental right that both children and parents have to preserve their "family integrity" and to apply the strict scrutiny standard when assessing that right. ${ }^{174}$ Children of same-sex parents have the same right to preserve their "family integrity."

While the substantive due process rights of children to maintain their family relationships have yet to be fully defined, judicial precedent has not foreclosed the possibility. Courts have recognized that children have rights under the Constitution and those rights include a right to "family integrity." 175 Additionally, this right will most likely receive strict scrutiny. ${ }^{176}$ If this right is to be protected in Indiana, then the legislature must enact laws that protect the right to "family integrity" for children of same-sex parents.

2. Children, as Well as Adults, Deserve Equal Protection Under the Laws.-In addition to a potential substantive due process argument, there is also an equal protection argument for children of same-sex parents. ${ }^{177}$ An analogy can be drawn between the protections that were denied non-marital children and the

166. Id. at $760-61$.

167. Id. at 760-61 n.11.

168. See generally id. at 745.

169. Roe v. Conn, 417 F. Supp. 769, 778 (1976).

170. Id. at 773 .

171. Id.

172. $I d$. at 777 .

173. Id.

174. See generally id.

175. Id. at 778 .

176. $I d$. at 777 .

177. See Catherine E. Smith, Equal Protection for Children of Same-Sex Parents, 90 WASH. U.L. REV. 1589, 1608 (2013). 
current state of children of same-sex parents. ${ }^{178}$ Historically, non-marital children were considered to be "filius nillius" or the "child of nobody" at common law. ${ }^{179}$ This idea resulted in children who were not only social outcasts, but also denied benefits of the state, such as inheritance or financial support from their parents. ${ }^{180}$ In Levy v. Louisiana, this doctrine was challenged, and it was the first time that the U.S. Supreme Court heard an equal protection case involving children. ${ }^{181} \mathrm{In}$ this case, five non-marital children were denied the "right to recover" from their mother's death because "morals and general welfare . . . discourages bringing children into the world out of wedlock."182 The Unites States Supreme Court overturned the Louisiana ruling saying that "it is invidious to discriminate against [the children] when no action, conduct, or demeanor of theirs is possibly relevant." 183

In 1972, the U.S. Supreme Court heard another Louisiana case in which the rights of non-marital children were again at issue. ${ }^{184}$ This case, Weber v. Aetna Casualty \& Surety Co., is perhaps one of the most well known cases involving the rights of non-marital children. ${ }^{185}$ This case concerned the rights of a man's nonmarital children to recover workmen's compensation benefits after he was killed at work. ${ }^{186}$ The non-marital children were denied access to the benefits under Louisiana law, whereas his legitimate children were able to recover. ${ }^{187}$ The Court concluded that Levy applied and that on equal protection grounds the children could not be denied access to the benefit. ${ }^{188}$ It is now well settled that "the government may not treat children born outside of a marriage differently than those born within one."189

Children of same-sex marriages can be considered a subset of non-marital children and therefore are entitled to equal protection. ${ }^{190}$ Both of these sets of children have no control over their status as non-marital or of being born into a same-sex family, and they also have no control over the decisions made by their parents. ${ }^{191}$ Additionally, these children suffer economic consequences by being denied state benefits, social security, and disability benefits. ${ }^{192}$

Certain state economic benefits flow to children from their parents and are

178. Id.

179. Id.

180. Id.

181. Levy v. Louisiana, 391 U.S. 68, 70 (1968); see also Smith, supra note 177, at 1610.

182. Levy, 391 U.S. at 70.

183. Id. at 72 .

184. Smith, supra note 177 , at 1613.

185. Id. at 1614 .

186. Weber v. Aetna Cas. \& Sur. Co., 406 U.S. 164, 166 (1972).

187. Id.

188. Id. at 173 .

189. Smith, supra note 177 , at 1614 .

190. Id. at 1615.

191. Id. at 1616 .

192. Id. at 1603-08. 
regulated by the states. ${ }^{193}$ In states where same-sex marriage is not recognized, such as Indiana, children are denied these rights because in same-sex families, the partner who is not biologically related to a child is considered a legal stranger; they are "precluded from forming a legal relationship" with the child. ${ }^{194}$ This lack of relationship results in certain economic inequities. ${ }^{195}$ For example, with inheritance, when a same-sex parent dies without a will, then the intestate scheme of a state that does not recognize same-sex marriage does not allow for the estate to go to the deceased's child. ${ }^{196}$ Another economic consequence is that children of same-sex couples are often denied child support when a relationship dissolves. ${ }^{197}$ Child support statutes typically do not extend the obligation of support beyond legal parents. ${ }^{198}$ This "remov[es] from the child the very source of funds that may have supported the child for a considerable period of time, especially if the 'non-biological' parent was the primary wage earner in the household." ${ }^{199}$ In A.C. v. N.J., the non-biological partner was the primary earner in the family, so by denying the child access to that parent, the child was also denied the economic support of the partner. ${ }^{200}$ This deprivation ultimately resulted in the child receiving healthcare through Medicaid. ${ }^{201}$ This goes against one of the rationales for establishing paternity, which is to solidify financial support for the child. ${ }^{202}$ It is generally accepted that in order to protect the public fisc, a "biological father should shoulder some financial responsibility for his biological child." 203 If states are interested in protecting children and the public fisc, then it would follow that identifying parents, rather than excluding them, would allow for this to happen more readily. ${ }^{204}$

193. These benefits include worker's compensation, inheritance, support, and wrongful death claims. See Smith, supra note 177, at 1605. The focus here is on state benefits because of the changing nature of federal benefits for same-sex couples since the decision in United States $v$. Windsor. See United States v. Windsor, 133 S. Ct. 2675, 2681 (2013). Currently, the federal government extends tax, bankruptcy, Medicare, and other benefits to same-sex couples validly married in a state that recognizes same-sex marriage. See Matt Apuzzo, More Federal Privileges to Extend to Same-Sex Couples, N.Y. TIMES, Feb. 8, 2014, http://www.nytimes.com/2014/ 02/09/us/more-federal-privileges-to-extend-to-same-sex-couples.html, archived at http://perma.cc/C2BY-TER8.

194. Smith, supra note 177 , at 1603.

195. Id. at 1603-08.

196. Id. at 1605 .

197. Id.

198. Lewis A. Silverman, Suffer the Little Children: Justifying Same-Sex Marriage from the Perspective of A Child of the Union, 102 W. VA. L. REV. 411, 447 (1999).

199. Id. at 447.

200. A.C. v. N.J., 1 N.E.3d 685, 687 (Ind. Ct. App. 2013).

201. Brief for Appellant at 6, A.C. v. N.J., 1 N.E.3d 685 (Ind. Ct. App. 2013) (No. 20A041301-DR-37).

202. Jacobs, supra note 30 , at 845 .

203. Id.

204. Id. 
Indiana's courts are struggling to resolve these practical family issues. ${ }^{205}$ Legislation is desperately needed in Indiana that will address these concerns and provide a legal framework to protect all families. A framework for this solution already exists in the Uniform Parentage Act and in other jurisdictions. ${ }^{206}$

\section{The Uniform PARENTAge ACt AND APPLICATION TO INDIANA}

In 1973, the Uniform Law Commission drafted the Uniform Parentage Act ("UPA"), which confirmed that "[t]he parent and child relationship extends equally to every child and every parent, regardless of the marital status of the parent." 207 This original version of the UPA embraced a "broader understanding of family" and recognized less traditional ways of creating a family. ${ }^{208}$ Fourteen states have adopted the 1973 version of the UPA, although, not Indiana. ${ }^{209}$ In 2002, the Uniform Law Commission recognized that the UPA needed to be amended in order to reflect the legal and scientific changes that had developed since the 1973 version. ${ }^{210}$ This updated version of the UPA combines two other acts that were promulgated by the American Law Institute in the decades between the 1973 Act and the current version. ${ }^{211}$ Those Acts were the Uniform Status of Children of Assisted Conception (1988) and the Uniform Putative and Unknown Fathers Act (1988). ${ }^{212}$ The 2002 UPA incorporates those acts and reflects the idea that families can be created through a variety of non-traditional means. ${ }^{213}$ The 2002 UPA focuses more on establishing the parentage of the child and leaves issues such as custody, visitation, and support to state law. ${ }^{214}$ This 2002 amended version of the UPA is currently law in nine states. ${ }^{215}$ When a state adopts a

205. See supra Part II.B.

206. See infra Part IV.

207. Parentage Act Summary, UNIFORM LAW COMMISSION, www.uniformlaws. org/ActSummary.aspx?title=Parentage $\% 20$ Act (last visited Oct. 12, 2014), archived at http://perma.cc/285D-TQ8A.

208. Jason C. Beekman, Same-Sex Second-Parent Adoption and Intestacy Law: Applying the Sharon S. Model of "Simultaneous" Adoption to Parent-Child Provisions of the Uniform Probate Code, 96 CoRnell L. REV. 139, 146 (2010) (“Adoption, for example, became a process to forge a parent-child relationship outside of the traditional model.").

209. Adopted by Alabama, California, Colorado, Illinois, Kansas, Minnesota, Montana, New Jersey, North Dakota, Ohio, Rhode Island, Texas, and Washington. Legislative Enactment Status: Parentage 1973, UNIFORM LAW COMMISSION, http://uniformlaws.org/LegislativeMap.aspx? title=Parentage $\% 20$ Act $\% 20$ (last updated Aug. 5, 2014), archived at $\mathrm{http}: / /$ perma.cc/X83P-X5P2.

210. Why States Should Adopt UPA, UNIFORM LAw COMMISSION, http://uniformlaws.org/ Narrative.aspx?title=Why\%20States\%20Should\%20Adopt\%20UPA (last visited Oct. 12, 2014), archived at $\mathrm{http}: / /$ perma.cc/3WES-AN2T.

211. Parentage Act Summary, supra note 207.

212. Id.

213. Beekman, supra note 208, at 146.

214. Why States Should Adopt UPA, supra note 210.

215. Currently Alabama, Delaware, New Mexico, North Dakota, Oklahoma, Texas, Utah, 
uniform law, such as the UPA, it is not required to adopt the entire law but can incorporate and modify the portions that are relevant to the state. ${ }^{216}$ Indiana, then, can adopt and modify the portions of the UPA that would be useful to address the issues of parentage for same-sex families.

\section{A. The Current Definitions in the UPA}

Article 2 of the 2002 amended UPA contains definitions of the parent-child relationship and is very comprehensive as it relates to fathers. ${ }^{217}$ Sections 201 and 204 of Article 2 contain the provisions for establishing a parent-child relationship. ${ }^{218}$ Section 201 provides for the establishment of the mother-child relationship and the father-child relationship separately. ${ }^{219}$ Section 201 indicates that, in addition to adoption and adjudication, a man can establish his parent-child relationship by an "unrebutted presumption of the man's paternity."220 Section 204 embodies this method of establishing paternity and provides five scenarios in which paternity is presumed. ${ }^{221}$ These include: when the child is born of the

Washington, and Wyoming have adopted the UPA. See Parentage Act Summary, supra note 207.

216. See 2B Sutherland Statutory Construction, Construction of Uniform AND Model State LaWs $\S 52: 5$ (7th ed. 2013).

217. UNIF. PARENTAGE ACT $\S \S 201-204$ (amended 2002).

218. Id.

219.

(a)The mother-child relationship is established between a woman and a child by: (1) the woman's having given birth to the child [, except as otherwise provided in [Article] 8]; (2) an adjudication of the woman's maternity; [or] (3) adoption of the child by the woman [; or (4) an adjudication confirming the woman as a parent of a child born to a gestational mother if the agreement was validated under [Article] 8 or is enforceable under other law]. (b) The father-child relationship is established between a man and a child by: (1) an unrebutted presumption of the man's paternity of the child under Section 204; (2) an effective acknowledgment of paternity by the man under [Article] 3 , unless the acknowledgment has been rescinded or successfully challenged; (3) an adjudication of the man's paternity; (4) adoption of the child by the man; [or] (5) the man's having consented to assisted reproduction by a woman under [Article] 7 which resulted in the birth of the child [; or (6) an adjudication confirming the man as a parent of a child born to a gestational mother if the agreement was validated under [Article] 8 or is enforceable under other law].

Id. $\S 201$.

220. Id. $\S 201(\mathrm{~b})(1)$.

221.

(a) A man is presumed to be the father of a child if: (1) he and the mother of the child are married to each other and the child is born during the marriage; (2) he and the mother of the child were married to each other and the child is born within 300 days after the marriage is terminated by death, annulment, declaration of invalidity, or divorce [, or after a decree of separation]; (3) before the birth of the child, he and the mother of the child married each other in apparent compliance with law, even if the 
marriage, when the child is born within 300 days of the termination of the marriage, when a child is born after a marriage is, or could be declared invalid, when a valid or invalid marriage occurs after the birth of a child, or if the father lived with the child for the first two years of the child's life and held himself out as the child's father. ${ }^{222}$

The UPA is comprehensive when it comes to establishing paternity and is less so when it comes to defining the mother-child relationship. ${ }^{223}$ Ostensibly, this would seem to be because, traditionally, courts have had little difficultly defining a mother but have frequently faced controversy-defining fathers. ${ }^{224}$ The UPA indicates that "cases involving disputed maternity are rare" and that "the new UPA is otherwise written in terms applicable to the determination of paternity." 225 The UPA does leave open the possibility that a "dispute may arise" about maternity, but that in that case "a judge ... should have little difficulty deciding which portions of the Act should be applied."226 This opens the door for judges to utilize discretion in applying the paternity provisions of the UPA to mothers in same-sex couples. ${ }^{227}$ Section 201 allows for a woman to establish her relationship with a child by giving birth to the child, adopting the child, or through adjudication. ${ }^{228}$ The UPA prohibits discrimination against families with unmarried parents, as stated in section 202: "A child born to parents who are not married to each other has the same rights under the law as a child born to parents who are married to each other."229 The UPA, however, does not specifically prohibit discrimination against same-sex couples. ${ }^{230}$ Despite this shortcoming, Indiana should adopt sections 201 and 204 of the UPA in a modified form that

attempted marriage is or could be declared invalid, and the child is born during the invalid marriage or within 300 days after its termination by death, annulment, declaration of invalidity, or divorce [, or after a decree of separation]; (4) after the birth of the child, he and the mother of the child married each other in apparent compliance with law, whether or not the marriage is or could be declared invalid, and he voluntarily asserted his paternity of the child, and: (A) the assertion is in a record filed with [state agency maintaining birth records]; (B) he agreed to be and is named as the child's father on the child's birth certificate; or (C) he promised in a record to support the child as his own; or (5) for the first two years of the child's life, he resided in the same household with the child and openly held out the child as his own. (b) A presumption of paternity established under this section may be rebutted only by an adjudication under [Article] 6.

Id. $\S 204$.

222. Id.

223. Compare id. § 204, with id. § 106.

224. Id. $\S 106 \mathrm{cmt}$. at 10 .

225. Id.

226. Id.

227. See, e.g., Elisa B. v. Superior Court, 117 P.3d 660 (Cal. 2005).

228. UNIF. PARENTAGE ACT $\S 201$ (a) (amended 2002).

229. Id. $\S 202$.

230. Id. 
would expand the mother-child relationship provisions to include the variety of ways the UPA identifies the father-child relationship. By doing so, Indiana courts could easily apply this Indiana Uniform Parentage Act, or INUPA, to same-sex families.

\section{B. Adopting the UPA in Indiana and Applying it to Indiana's Same-Sex Families}

Indiana recently began to recognize same-sex marriages. ${ }^{231}$ While this would alleviate parentage issues for those same-sex couples in Indiana who are married, not all same-sex couples in Indiana are currently married nor is it clear how the current Indiana code would apply to a same-sex family. Therefore, it is still important for Indiana to ensure that the current laws are meeting the needs of Indiana's diverse families. Indiana should adopt sections 201 and 204 of the UPA for mothers as well for fathers, ${ }^{232}$ as the INUPA, in order to fill the gaps in Indiana law that the courts have identified. ${ }^{233}$ This would allow for section 201 to expand, establishing a mother-child relationship through "an unrebutted presumption of the [woman's maternity] of the child under [s]ection 204."234 Then, section 204, which provides for presumptions of paternity, would establish a presumption of maternity under INUPA. ${ }^{235}$ Allowing for the presumption of both mothers and fathers would permit partners of same-sex couples, of either gender, to establish their parentage of a child. ${ }^{236}$ Section 204(a)(5) of INUPA would be the most useful provision for unmarried same-sex partners who relocate to Indiana or where one partner did not adopt the child, such as in A.C. v. N.J. ${ }^{237}$ This new INUPA section would allow for a presumption of [maternity] if "for the first two years of the child's life, [she] resided in the same household with the child and openly held out the child as [her] own." ${ }^{238}$ In practice, Indiana courts could apply this new section of INUPA to a same-sex family who moves to Indiana and is not married. This provision would allow for a partner who may be excluded under Indiana law to establish parentage of a child without having to go through the adoption process. ${ }^{239}$ As long as the person could show that he or she held the child out as his or her own and lived with the child for longer than two

231. See Baskin v. Bogan, 766 F. $3 d 648$ ( $7^{\text {th }}$ Cir. 2014), cert denied, 135 S. Ct. 316 (2014).

232. See Maggie Manternach, Where Is My Other Mommy?: Applying the Presumed Father Provision of the Uniform Parentage Act to Recognize the Rights of Lesbian Mothers and Their Children, 9 J. GENDER, RACE, \& JusT. 385, 387 (2005).

233. See In re Paternity of Infant T., 99 N.E.2d 843, 843 (Ind. 2013), trans. denied (Rush, J., dissenting); A.C. v. N.J., 1 N.E.3d 685, 692 (Ind. Ct. App. 2013).

234. UNIF. PARENTAGE ACT $\S 201$ (amended 2002).

235. See id. § 204.

236. See Manternach, supra note 232, at 417.

237. See A.C., 1 N.E.3d at 685.

238. Unif. Parentage ACt $\S 204$ (amended 2002).

239. See id. 
years, then that parent would have established a parent-child relationship. ${ }^{240}$ This provision would have allowed the partner in A.C. v. N.J. to assert her parentage. ${ }^{241}$ The biological mother and partner lived together as a family for two years, and the partner held her herself out as the child's mother. ${ }^{242}$ The partner provided financially for the child and was even listed as the emergency contact on a school form. ${ }^{243}$ It appears that she would easily meet the two requirements of holding the child out as her own and living with the child for the first two years of the child's life, thus establishing parentage under the newly created INUPA. ${ }^{244}$

Section 204(a)(4) of INUPA would also permit a voluntary assertion of paternity or maternity after a child is born, whether there is an invalid or valid marriage. ${ }^{245}$ This voluntary assertion would be "in a record filed with [the Indiana Department of Health]," "on the child's birth certificate," or if "he [or she] promised in a record to support the child as his [or her] own." ${ }^{246}$ This would permit partners in a same-sex couple to assert their parentage without having to hold the child out as their own for two years. ${ }^{247}$ Under this provision of INUPA, the partner in A.C. v. N.J. could have established herself as a presumed parent because she could assert her parentage by "promis[ing] in a record to support the child as her own." 248 The partner and biological mother had agreed to raise the child together and that the partner would be the child's "second parent."249 Although the agreement was not memorialized in a record, as the INUPA would require, if it was, the partner could have established her parentage because the biological mother did "not dispute that she agreed to raise [c]hild with [p]artner."250 Additionally, the partner took on financial responsibility for the child and provided support. ${ }^{251}$ If the INUPA were available to the partner, she simply could have established in a record that they agreed that "she would always be [the child's] mom"252 and thus confirming her parentage of the child. ${ }^{253}$ This would create another path for same-sex partners to establish parentage.

To ensure that Indiana's laws protect all children, Indiana should adopt

240. In Indiana, courts have held that a same-sex couples can adopt under Indiana's Adoption Act. IND. CODE §§ 31-19-2-2(a), 31-19-2-4 (2013); see also In re Infant Girl W., 845 N.E.2d 229 (Ind. Ct. App. 2006).

241. See A.C., 1 N.E.3d at 687.

242. $I d$.

243. Id.

244. See Unif. Parentage Act $\S 204(a)$ (4) (amended 2002).

245. See id. $\S 204(\mathrm{a})(4)$.

246. See id. § 204(a)(4)(A)-(C).

247. Id.

248. A.C, 1 N.E.3d at 685 .

249. Id. at 689 .

250. Id.

251. Brief for Appellant at 4, A.C. v. N.J., 1 N.E.3d 685 (Ind. Ct. App. 2013) (No. 20A041301-DR-37).

252. Id.

253. Unif. Parentage ACt $\S 204(a)(4)(C)$ (amended 2002). 
Sections 201 and 204 of the UPA, for both mothers and fathers, as the INUPA. ${ }^{254}$ This would allow for the same level of recognition of a mother that exists in the current UPA for a father and would provide a way for Indiana law to recognize same-sex parents, such as the partner in A.C. v. N.J. ${ }^{255}$

\section{Application of the UPA to Same-Sex Custody Disputes}

Despite the UPA's shortcomings, other jurisdictions that have adopted the UPA have applied it to same-sex parentage. ${ }^{256}$ California is one of those jurisdictions. California adopted the 1973 version of the UPA ${ }^{257}$ and codified it as Part 3 of Division 12 covering parent and child relationships. ${ }^{258}$ By adopting the UPA, California has been able to resolve same-sex custody issues. In Elisa B. v. Superior Court, the California Supreme Court heard a case involving a same-sex couple who exchanged rings, held each other out as each other's partner, and felt as if they were in a committed relationship. ${ }^{259}$ Four years later, they decided to have children together, and because both of them wanted to carry a child, they were both inseminated with the same sperm so that their children would be half siblings. ${ }^{260}$ One partner gave birth to a son, while the other gave birth to twins. ${ }^{261}$ It was decided that the partner who birthed the son would return to work while the other partner would stay home with the three children. ${ }^{262}$ Both partners shared parenting duties for all three of the children. ${ }^{263}$ After a few years, their relationship deteriorated, and they separated. ${ }^{264}$ The working partner agreed to provide support to the stay-at-home partner and the twins. ${ }^{265}$ The working partner then lost her job and sought to discontinue paying the support payments. ${ }^{266}$

The California Supreme Court found that the working mother had to continue paying the support payments because she could be considered the mother of the children and there is "no reason why both parents of a child cannot be women."267 In doing this, the California Supreme Court applied several sections of the UPA

254. See id. $\S \S 201,204$.

255. See id.

256. See, e.g., Parentage Act (1973), UnIFORM LAw COMMISSION, http://www.uniformlaws. org/Act.aspx?title=Parentage $\% 20$ Act $\% 20$ (last visited Oct. 12, 2014), archived at http://perma.cc/ N8VV-6PLS.

257. Id.

258. CAL. FAM. CODE $\S 7600$ et seq. (West 2013).

259. Elisa B. v. Superior Court, 33 Cal. Rptr. 3d 46, 48 (Cal. 2005).

260. Id.

261. Id.

262. Id.

263. Id.

264. $I d$.

265. $I d$.

266. Id. at 48-50.

267. Id. at 52-53. 
to same-sex couples. ${ }^{268}$ First, the court stated that section 2 of the UPA indicates that a parent-child relationship can exist regardless of the marital status of the parents. ${ }^{269}$ Even though the twins' mothers were not married, a parent child relationship could exist. ${ }^{270}$ The court then used section 4(a) of the California Family Code, which is similar to section 204, and outlines several scenarios when a man could be considered the natural father of a child. ${ }^{271}$ These scenarios include receiving the child into the home and holding the child out as his own. ${ }^{272}$ The court interpreted that these provisions establishing paternity could also be used to establish maternity "insofar as practicable." ${ }^{273}$ The court also said that even " $[t]$ hough most of the decisional law has focused on the definition of the presumed father, the legal principles concerning the presumed father apply equally to a woman seeking presumed mother status." 274 Using these portions of the UPA which California had adopted into their Family Code, the court finally concluded that the working mother could be considered the mother of the twins who were not biologically related to her because she brought them into her home and held them out as her own. ${ }^{275}$ Additionally, the court considered the effect that its holding would have if it concluded that the working mother was not the legal mother of the twins. ${ }^{276}$ It concluded that this outcome would leave the children with only one parent. ${ }^{277}$ The court interpreted the intent of the California Legislature as "implicitly recogniz[ing] the value of having two parents, rather than one, as a source of both emotional and financial support, especially when the obligation to support the child would otherwise fall to the public." 278

If Indiana prefers a two-parent household, as it claims in the Parenting Time Guidelines "[a] young child thrives when both parents take an active role in parenting," 279 then Indiana must be prepared to recognize different types of parents. Adopting an Indiana version of the UPA, or INUPA, will go a long way toward Indiana having a Family Code that is "clear, concise and easy to interpret

268. Id at 50-53.

269. Id. at 51-52; see CAL. FAM. CODE $§ 7602$ (West 2013).

270. At the time of this decision, California was not recognizing same-sex marriages. See Hollingsworth v. Perry 133 S. Ct. 2652, 2668 (2013) (holding that after California officials declined to defend a ballot initiative defining marriage as between one man and one woman in the California Constitution, petitioners did not have standing to challenge a district court ruling that the ballot initiative was unconstitutional).

271. Elisa B., 33 Cal. Rptr.3d at 50-52; see FAM. $§ 7611$.

272. Elisa B., 33 Cal. Rptr.3d at 50-51; see FAM. $\$ 7611$

273. Elisa B., 117 P.3d at 50-55 (citing In re Salvador M., 4 Cal. Rptr.3d 705 (Cal. Ct. App. 2003)).

274. Id. at 53-55.

275. Id. at 54-57.

276. Id. at 56-57.

277. Id.

278. Id.

279. IND. CT. R. APPENDIX tit. 34 §I (2013) (Ind. Parenting Time Guidelines). 
and apply." ${ }^{280}$ This would allow the Indiana legislature to fulfill Judge Friedlander and Justice Rush's requests for guidance in this murky area of the law, ${ }^{281}$ and would ultimately benefit all the children of Indiana equally. ${ }^{282}$

\section{CONCLUSION}

Indiana courts are struggling to resolve matters relating to same-sex families in Indiana. ${ }^{283}$ The recent Indiana Court of Appeals decision in A.C. v. N.J. indicates that Indiana family law is not providing protection for all of Indiana's families. ${ }^{284}$ This is also an area where the Indiana courts, specifically Justice Rush and Judge Friedlander, have asked the Indiana legislature for guidance. ${ }^{285}$ The Indiana General Assembly has not yet heeded this call. Traditionally, identifying the parentage of a child was a straightforward matter under the "marital presumption." 286 This doctrine identified the parents of a child as a mother and her husband. ${ }^{287}$ This efficient definition was useful because children were largely thought of as property and were needed for labor. ${ }^{288}$ While this might have been a useful way of identifying parents, families look different than they did when family laws were first being enacted. ${ }^{289}$ This change in family roles from a largely economic one to a relationship-based role is reflected in the U.S. Supreme Court's decision in the "biology plus" cases. ${ }^{290}$ These cases illustrate that biology is often not enough to establish a father-child relationship, but a father must also demonstrate a "full commitment to the responsibilities of parenthood." 291 Despite this definition, the Court has not yet decided a case that expressly defines the rights of a same-sex parent, so the states are free to define that relationship.

Indiana's current laws do not provide a workable definition of parentage for unmarried same-sex families and Indiana's case law further confirms this point. In cases such as A.C. v. N.J. and In re A.B., Indiana courts have struggled to define the rights of same-sex parents. ${ }^{292}$ After these cases, it appears same-sex

280. IND. CODE § 31-10-1-1 (2013).

281. See In re Paternity of Infant T., 99 N.E.2d 843,843 (Ind. 2013), trans. denied (Rush, J., dissenting); A.C. v. N.J., 1 N.E.3d 685, 692 (Ind. Ct. App. 2013).

282. See A.C., 1 N.E.3d at 685.

283. See Part II.B.

284. See In re Paternity of Infant T., 99 N.E.2d at 843; A.C., 1 N.E.3d at 692.

285. See In re Paternity of Infant T., 99 N.E.2d at 843; A.C., 1 N.E.3d at 692.

286. Murphy, supra note 14, at 326.

287. $I d$.

288. Id.

289. Assisted Reproductive Technology: Most Recent ART Data, CENTERS FOR DISEASE CONTROL AND PREVEnTION, http://www.cdc.gov/ART (last visited July10, 2014), archived at http://perma.cc/M766-RKEE.

290. Jacobs, supra note 30 , at 827 .

291. Lehr v. Robertson, 463 U.S. 248, 261 (1983).

292. See A.C. v. N.J., 1 N.E.3d 685 (Ind. Ct. App. 2013); In re A.B., 818 N.E.2d 126 (Ind. Ct. 
parents at least have standing to assert their parental right, but any rights beyond that remain unclear. ${ }^{293}$ Research shows that the presence of same-sex families is not something that will decrease; in fact, it will most likely increase as more and more states, and now the federal government, recognize same-sex marriage. ${ }^{294}$ As same-sex partners increasingly create families, there are no laws in Indiana that apply to them, and, ultimately, protect them. ${ }^{295}$ Without a clear directive from the legislature, Indiana courts are left to make these decisions on their own. ${ }^{296}$ Children have rights under the Constitution and have a legitimate substantive due process and equal protection argument to preserving their relationship with a same-sex parent. In order to protect children's substantive due process right to "family integrity" and to provide equal protection under the law, Indiana should adopt a modified version of the Uniform Parentage Act ("UPA").

Indiana should specifically adopt sections 201 and 204 of the UPA, as the Indiana Uniform Parentage Act ("INUPA"). ${ }^{297}$ The INUPA would include a modified version of section 201 and 204 that would expand the presumptions of paternity to mothers and establish presumptions of maternity. Incorporating these portions of the UPA as the INUPA would allow for Indiana courts to more readily identify parents in a same-sex family. Same-sex parents could then be presumed to be a parent by holding themselves out as a parent for two years or by voluntarily acknowledging their parentage of a child. This would fill the gap in Indiana law as identified by courts and protect all of Indiana's children and families.

App. 2004), vacated by King v. S.B., 837 N.E.2d 965 (Ind. 2005).

293. See A.C., 1 N.E.3d at 685.

294. Richard Socarides, The Growing Impact of the Supreme Court's Gay-Marriage Ruling, NEW YORKER (Jan. 27, 2014), http://www.newyorker.com/online/blogs/newsdesk/2014/01/thewidening-impact-of-the-supreme-courts-gay-marriage-ruling.html, archived at http://perma.cc/ 3JDN-7HG3.

295. A.C., 1 N.E.3d at 692.

296. Id. at 693.

297. See Unif. Parentage ACt $\S \S 201,204$ (amended 2002). 